\section{Factors associated with unprotected sexual practice among men and women with mental illnesses in Brazil}

\author{
Fatores associados com a prática do sexo \\ desprotegido entre homens e mulheres \\ com transtornos mentais no Brasil
}

\author{
Los factores asociados con la práctica del sexo \\ sin protección entre hombres y mujeres con \\ trastornos mentales en Brasil
}

\author{
1 Universidade Federal de \\ Minas Gerais, Belo Horizonte, \\ Brasil. \\ Correspondence \\ E. R. M. Peixoto \\ Universidade Federal de \\ Minas Gerais. \\ Av. Prof. Alfredo Balena 190, \\ Belo Horizonte, $M G$ \\ 30130-100, Brasil. \\ elianer@ufmg.br
}

\section{Abstract}

This study estimated the rate and correlates of recent unprotected sex among sexually active psychiatric patients in Brazil, stratified by gender. The prevalence of unprotected sex among women and men were $89 \%$ and $77 \%$, respectively. Significant correlates with unprotected sex were: being married/in union, living with children/ partner, and cigarette smoking in both genders; lower income, depression and anxiety diagnoses among men only; older age, no previous HIV testing, sex under the influence of alcohol/drugs, and verbal violence among women only. Interventions to reduce risk behavior among psychiatric patients in Brazil are urgent and should take into account gender differences.

HIV; Sexual Behavior; Mental Disorders
Eliane Rezende de Morais Peixoto 1 Fabiana Cristina Ribeiro de Barros 1 Mark Drew Crosland Guimarães 1

\section{Resumo}

Este estudo estimou a prevalência e os fatores associados com o sexo desprotegido recente entre pacientes psiquiátricos sexualmente ativos no Brasil, estratificados por sexo. A prevalência de sexo desprotegido entre mulheres e homens foi $89 \%$ e $77 \%$, respectivamente. Os fatores associados significativamente com o sexo desprotegido foram: estar casado/em união, viver com filhos/ parceiros, e tabagismo em ambos os sexos; baixa renda e diagnósticos de depressão e ansiedade apenas entre homens; idade maior que 40 anos, nenhum teste prévio para o HIV, sexo sob a influência de álcool/drogas e violência verbal apenas entre as mulheres. Intervenções para reduzir comportamentos de risco entre pacientes psiquiátricos no Brasil são urgentes e devem considerar as diferenças de gênero.

HIV; Comportamento Sexual; Transtornos Mentais 


\section{Introduction}

Adults with severe mental illnesses are at increased risk of HIV infection with higher rates of unprotected sex as compared to the general population $1,2,3$.

There is evidence that rates of unprotected sex are higher among women than men - respectively, $56 \%$ and $43 \%$ of patients with severe mental illnesses in the last three months in the USA $4 ; 82 \%$ and $65 \%$ in the last year also among patients with severe mental illnesses also in the USA 5; and $84 \%$ and $77 \%$ among patients with chronic mental illness in Brazil during lifetime 6 . These differences are also consistent among women and men in the general population - respectively, $78 \%$ and $72 \%$ among Brazilians 15 to 64 years old in the last year 2 ; and $46 \%$ and $33 \%$ among students in the USA at last sexual intercourse ${ }^{7}$. Gender-based inequalities, including cultural values (e.g., men should have many partners, women should be monogamous), socioeconomic context (e.g. unequal access to education, employment, increased violence, and restricted reproductive rights among women) which potentially place women at a disadvantage for negotiating safer sex or refusing unwanted sex, can partially explain differential rates of unprotected sex reported among men and women 5,8 .

Several correlates of unprotected sex among people with mental illness have been identified including gender, age, multiple partners, history of sexually transmitted diseases (STDs), exchange of sex for money/drug, sex under the influence of alcohol or drugs, substance use, and psychiatric diagnoses 1 . We have previously assessed correlates of unsafe sex among psychiatric patients in Brazil 6, and female gender, depression and anxiety, among other factors, were independently associated with lifetime unsafe sex. In that report we used lifetime time-frame and considered those abstinent as safe sex.

There is also evidence that men and women with mental illnesses differ with regard to sociodemographic, behavioral, contextual as well as clinical characteristics. Men are usually more frequently single, with younger age at onset of psychiatric symptoms, with higher rates of illicit drug and alcohol use as well as cigarette smoking, and greater number of sexual partners 1,9,10,11. In addition, men tend to have higher rates of hospitalization, more severe (e.g. psychoses) and substance use related diagnoses, while women tend to have higher rates of anxiety and depression $11,12,13,14,15$. It is not clear though whether differences in the rates of unprotected sex among men and women may be explained by clinical or con- textual factors among people with mental illness under care.

Few studies have focused on comparing differences in the determinants of risky sexual behavior among men and women with mental illnesses, separately. In addition, estimates and correlates of unprotected sex among psychiatric patients are largely based on studies conducted with varying methodology, including small populations, often restricted to more severe patients and different time frames (from three months to lifetime) or denominators (e.g. inclusion of abstinent, sexually active only). While lifetime risk behavior assessment and the inclusion of abstinence in the denominator may reflect overall lifespan exposure to HIV, these may actually overestimate the rates of unprotected sex. Analyzing the prevalence and factors that potentially lead sexually active men and women to practice unprotected sex in a more recent time frame may be more useful for surveillance purposes. In addition, sexual histories obtained from more recent periods may generate more reliable data due to better recall. Thus, the aim of this study was to estimate the rate of unprotected sex in the last six months among sexually active psychiatric patients in Brazil under care and to assess whether correlates of unprotected sex differ by gender, taking into account sociodemographic, clinical, and behavioral/contextual factors.

\section{Method}

\section{Study design and sample}

This study draws on data from the HIV Seroprevalence Survey in Mental Health (PESSOAS Project), a national cross-sectional multicenter study conducted in 11 public psychiatric hospitals and in 15 public mental health outpatient clinics (CAPS) in Brazil in 2006. The PESSOAS Project was originally designed to estimate HIV, syphilis, and hepatitis B and C seroprevalence and to assess risk behaviors among psychiatric patients as detailed elsewhere ${ }^{16}$. The sample size was obtained using a two-stage probability sampling - centers were selected, followed by random selection of patients - proportional to the type of care (hospital or CAPS) and the distribution of reported AIDS cases by Brazilian region. Those CAPS which exclusively treated substance use disorders, since primary diagnoses were excluded due to the possibility of overestimating selected risk behavior and/or prevalence rates. Eligibility criteria included adult (18 years old and over) psychiatric patients under care either at hospital or adult CAPS, who were capable of 
providing written informed consent, and were able to answer the questionnaire. A preliminary assessment adapted from the Mini-Mental State Examination (brief-MMSE) was carried out by a trained mental health professional to evaluate the patient's capacity to participate in and understand the aims of the study. In addition, the presence of acute psychosis was ascertained using a qualitative assessment. To evaluate unprotected sex in the last six months, only those who reported being sexually active in this same time frame were included in this analysis.

Ethical approval was obtained from each treatment site, from the Ethics Research Committee of the Minas Gerais Federal University (UFMG/ETIC 125/03) and the Brazilian National Ethics Research Committee (CONEP 592/2006).

\section{Exposure and event measurements}

A person-to-person interview using a semistructured questionnaire was conducted by an experienced and trained mental health care professional for obtaining sociodemographic, clinical and behavioral data. The protocol, questionnaires and procedures were tested and validated in a pilot study and the measurements were previously tested for reliability 16 . The outcome measure of interest in this study was unprotected sex in the last six months and it was defined as not using condoms in all sexual relations in the last six months, including vaginal, anal or oral intercourses. Potential explanatory characteristics investigated were grouped in: (1) Sociodemographics (i.e., type of recruitment center, skin color, age, marital status, schooling, family income in the last month, current housing partnership); (2) Clinical (i.e., main psychiatric diagnosis, previous psychiatric hospitalization, history of sexually transmitted disease in the last year [STDs], and previous HIV testing); (3) Behavioral/contextual (i.e., age at first sexual intercourse, refusal of condom use by partner, receiving/offering money and/or drugs for sex, sex under the influence of drugs and/or alcohol, multiple sexual partners in the past six months, lifetime alcohol, or illicit drug use, cigarette smoking, lifetime verbal, physical and sexual violence, HIV/AIDS knowledge, and self-perception of HIV risk). Psychiatric diagnoses were obtained from medical charts and coded according to the $10^{\text {th }}$ revision of the International Classification of Diseases (ICD10) 17 . When more than one psychiatric diagnosis was present, these were hierarchically grouped according to clinical severity and grouped as follows: (1) psychotic disorders, depression with psychotic symptoms, and bipolar disorder; (2) depression and anxiety; (3) substance use disor- der; and (4) others. Adequate HIV/AIDS knowledge was defined as having eight or more correct answers to ten previously tested questions regarding transmission and prevention of HIV. HIV risk self-perception was classified as none, some or high risk, and did not know.

\section{Statistical analysis}

A descriptive analysis was carried out and Pearson's chi-square test was performed for the analysis of categorical data, stratified by gender. The prevalence of recent unprotected sex was estimated by dividing the number of participants who reported not using condoms in all sexual practices in the last six months by the number of sexually active participants in the same timeframe, stratified by gender. The magnitude of the associations between putative risk factors and unprotected sex was estimated by odds ratio (OR) with $95 \%$ confidence interval $(95 \% \mathrm{CI})$. The level of significance was 0.05 . The independent effect of potential explanatory variables was assessed by logistic regression in two steps. First, variable with $\mathrm{p}$-values equal or less than 0.20 obtained in the univariate analysis or with epidemiological relevance were assessed separately for each previously defined group, i.e., sociodemographics, clinical and behavioral/contextual, for men and women. A sequential deletion strategy was used and only those variables with $\mathrm{p}$-value equal to or less than 0.10 were included in each final intermediate model, separately for men and women. Second, these variables were fitted in one overall multivariate model, also using a sequential deletion strategy. Only variables with p-value less than 0.05 remained in the final logistic regression model, for each gender stratum. Goodness of fit of the final model was assessed by Hosmer-Lemeshow test. SAS System 9.0 (SAS Inst., Cary, USA) was used for data analysis and Paradox Windows 11.0 (Borland International, Scotts Valley, USA) for database management.

\section{Results}

\section{Participant characteristics}

Among the 3,255 patients recruited, 492 (15.1\%) were not eligible to participate in the study. Of 2,763 patients eligible, 288 (10.4\%) were nonparticipants. The main reasons for nonparticipation were refusals (52\%), not being located (19.1\%), missed appointments (8\%), not eligible (3.8\%), legally incapable $(1 \%)$, death $(0.7 \%)$, and miscellaneous reasons (15.4\%). Not statistically significant differences were seen between partici- 
pants and nonparticipants regarding age, gender, schooling, or psychiatric diagnosis $(\mathrm{p}>0.05) 16$.

Among the 2,475 patients interviewed, 1,475 $(60 \%)$ were sexually active in the last six months. Among these, 791 (53.6\%) were women and 684 (46.4\%) were men. The prevalence of unprotected sex in the last six months was $88.8 \%$ (95\%CI: 86.3; 90.9) for women and $77.2 \%$ (95\%CI: 73.9; 80.2) for men (Table 1).
While there were higher proportions of women who were white $(52.7 \%)$, married or in union (56.8\%), who lived with children and/or a partner (73.6\%), and with less than five years of schooling (47.5\%), men presented a higher proportion of those aged 40 years or younger (54.5\%), and with a family income greater than the Brazilian minimum wage (US\$200) in the last month (51.7\%).

Table 1

Descriptive characteristics stratified by gender among sexually active patients with mental illness. PESSOAS Project, Brazil, 2006 ( $\mathrm{N}=1,475)$.

\begin{tabular}{|c|c|c|c|}
\hline Characteristics & $\begin{array}{c}\text { Men }(N=684 *) \\
n(\%)\end{array}$ & $\begin{array}{c}\text { Women }(\mathrm{N}=791 \text { *) } \\
\text { n (\%) }\end{array}$ & p-value \\
\hline \multicolumn{4}{|l|}{ Sociodemographic } \\
\hline \multicolumn{4}{|l|}{ Type of recruitment center } \\
\hline CAPS & $373(54.5)$ & $578(73.1)$ & $<0.001$ \\
\hline Hospital & $311(45.5)$ & $213(26.9)$ & \\
\hline \multicolumn{4}{|l|}{ Skin color } \\
\hline White & $332(48.5)$ & $416(52.7)$ & 0.115 \\
\hline Black/Mulatto & $352(51.5)$ & $374(47.3)$ & \\
\hline \multicolumn{4}{|l|}{ Age (years) } \\
\hline$\leq 40$ & $373(54.5)$ & $397(50.2)$ & 0.096 \\
\hline$>40$ & $311(45.5)$ & $394(49.8)$ & \\
\hline \multicolumn{4}{|l|}{ Marital status } \\
\hline Married or in union & $246(36.0)$ & $449(56.8)$ & $<0.001$ \\
\hline Other (single/separated/widower) & $438(64.3)$ & $342(43.2)$ & \\
\hline \multicolumn{4}{|l|}{ Schooling (years) } \\
\hline$<5$ & $309(45.6)$ & $372(47.5)$ & 0.476 \\
\hline$\geq 5$ & $368(54.4)$ & $411(52.5)$ & \\
\hline \multicolumn{4}{|l|}{ Family income in the last month ** } \\
\hline$>$ US\$ 200 & $345(51.7)$ & $361(46.8)$ & $<0.001$ \\
\hline$\leq$ US\$ 200 & $129(19.3)$ & $222(28.8)$ & \\
\hline \multicolumn{4}{|l|}{ Current housing partnership } \\
\hline Living with children and/or partner & $245(35.8)$ & $580(73.6)$ & $<0.001$ \\
\hline Living with others or alone & $439(64.2)$ & $208(26.4)$ & \\
\hline \multicolumn{4}{|l|}{ Clinical } \\
\hline \multicolumn{4}{|l|}{ Psychiatric diagnoses (ICD-10) } \\
\hline \multicolumn{4}{|l|}{ symptoms } \\
\hline Depression/Anxiety & $83(12.1)$ & $235(29.7)$ & \\
\hline Substance use disorder & $117(17.1)$ & $24(3.0)$ & \\
\hline Other & $107(15.6)$ & $165(20.9)$ & \\
\hline \multicolumn{4}{|l|}{ Previous hospitalization } \\
\hline Yes & $423(62.0)$ & $365(46.3)$ & $<0.001$ \\
\hline No & $259(38.0)$ & $424(53.7)$ & \\
\hline \multicolumn{4}{|l|}{ STD in the last year } \\
\hline Yes & $48(7.2)$ & $101(13.2)$ & $<0.001$ \\
\hline No & $615(92.8)$ & $664(86.8)$ & \\
\hline
\end{tabular}

(continues) 


\begin{tabular}{|c|c|c|c|}
\hline Characteristics & $\begin{array}{c}\text { Men }(N=684 *) \\
n(\%)\end{array}$ & $\begin{array}{c}\text { Women }(\mathrm{N}=791 *) \\
\mathrm{n}(\%)\end{array}$ & $\mathrm{p}$-value \\
\hline \multicolumn{4}{|l|}{ Clinical } \\
\hline \multicolumn{4}{|l|}{ Previous HIV testing } \\
\hline Yes & $216(32.1)$ & $268(34.7)$ & 0.300 \\
\hline No & $457(67.9)$ & $505(65.3)$ & \\
\hline \multicolumn{4}{|l|}{ Behavioral } \\
\hline \multicolumn{4}{|l|}{ Age of first sexual intercourse (years) } \\
\hline$<18$ & $454(69.4)$ & $404(52.4)$ & $<0.001$ \\
\hline$\geq 18$ & $200(30.6)$ & $367(47.6)$ & \\
\hline \multicolumn{4}{|l|}{ Condom use in the last six months } \\
\hline Always & $156(22.8)$ & $89(11.2)$ & $<0.001$ \\
\hline Inconsistent use & $528(77.2)$ & $702(88.8)$ & \\
\hline \multicolumn{4}{|l|}{ Refusal of condom use by partner } \\
\hline Yes & $158(23.6)$ & $308(40.0)$ & $<0.001$ \\
\hline No & $511(76.4)$ & $463(60.0)$ & \\
\hline \multicolumn{4}{|c|}{ Received/Offered money or drugs for sex } \\
\hline Yes & $318(47.0)$ & $130(16.6)$ & $<0.001$ \\
\hline No & $358(53.0)$ & $653(83.4)$ & \\
\hline \multicolumn{4}{|c|}{ Sex under the influence of drugs or alcohol } \\
\hline Yes & $322(47.4)$ & $160(20.4)$ & $<0.001$ \\
\hline No & $357(52.6)$ & $626(79.6)$ & \\
\hline \multicolumn{4}{|c|}{ Number of sexual partners in the last six months } \\
\hline Only one & $337(36.6)$ & $548(69.3)$ & $<0.001$ \\
\hline$>1$ & $250(49.3)$ & $128(16.2)$ & \\
\hline \multicolumn{4}{|l|}{ Lifetime alcohol use } \\
\hline Yes & $581(85.1)$ & $447(56.6)$ & $<0.001$ \\
\hline No & $102(14.9)$ & $343(43.4)$ & \\
\hline \multicolumn{4}{|l|}{ Lifetime illicit drug use } \\
\hline Yes & $289(42.3)$ & $139(17.6)$ & $<0.001$ \\
\hline No & $394(57.7)$ & $651(82.4)$ & \\
\hline \multicolumn{4}{|l|}{ Lifetime cigarette smoking } \\
\hline Yes & $566(83.0)$ & $506(64.4)$ & $<0.001$ \\
\hline No & $116(17.0)$ & $280(35.6)$ & \\
\hline \multicolumn{4}{|l|}{ Lifetime verbal violence } \\
\hline Yes & $477(69.7)$ & $597(75.6)$ & $<0.012$ \\
\hline No & $207(30.3)$ & $193(24.4)$ & \\
\hline \multicolumn{4}{|l|}{ Lifetime physical violence } \\
\hline Yes & $408(59.9)$ & $463(58.5)$ & 0.592 \\
\hline No & $273(40.1)$ & $328(41.5)$ & \\
\hline \multicolumn{4}{|l|}{ Lifetime sexual violence } \\
\hline Yes & $84(12.4)$ & $227(28.8)$ & $<0.001$ \\
\hline No & $596(87.7)$ & $562(71.2)$ & \\
\hline \multicolumn{4}{|l|}{ HIV/AIDS knowledge } \\
\hline Good & $431(64.1)$ & $503(64.2)$ & 0.967 \\
\hline Poor & $241(35.9)$ & $280(35.8)$ & \\
\hline \multicolumn{4}{|l|}{ HIV risk self-perception } \\
\hline High/Some risk/Do not know & $444(66.8)$ & $539(70.1)$ & 0.176 \\
\hline No risk & $221(33.2)$ & $230(29.9)$ & \\
\hline
\end{tabular}

CAPS: Public Mental Health Outpatient Clinics; ICD-10: 10th revision of the International Classification of Diseases; OR: odds ratio; STD: sexually transmitted diseases.

* Total varies due to missing information;

** Brazilian minimum wage in $2006=$ US\$ 200. 
A higher proportion of men had diagnoses of psychoses, bipolar disorder or depression with psychotic symptoms (55.1\%) and previous psychiatric hospitalization $(62 \%)$, while a higher proportion of women had depression and anxiety (29.7\%), a history of STDs in the last year (13.2\%) and previous HIV testing (34.7\%).

Regarding the behavioral characteristics, a higher proportion of men reported their first sexual intercourse before 18 years old (69.4\%), received or offered money or drugs for sex (47\%), have had sex under the influence of drugs or alcohol (47.4\%), and had more than one sexual partner in the last six months (49.3\%). In addition, there was a higher proportion of men who reported alcohol and illicit drug use $(85.1 \%$ and $42.3 \%$, respectively), lifetime cigarette smoking (83\%), and lifetime physical violence (59.9\%). Also, they presented higher proportions of perceiving themselves as having no risk of HIV infection (33\%). On the other hand, women reported more refusal of condom use by their partners (40\%), and lifetime verbal and sexual violence $(75.6 \%$ and $28.8 \%$, respectively). Finally, similar proportions of men and women had good HIV/AIDS knowledge (64\%).

\section{Univariate and multivariate analyses}

Univariate analysis indicated that among both genders, the odds of practicing recent unprotected sex was statistically greater $(p<0.05)$ among those older than 40 , married or in union, and who were living with children and/or a partner (Table 2). The odds of recent unprotected sex was more than two-fold higher among women with less than five years of schooling.

Men with depression and anxiety diagnoses were statistically more likely to practice recent unprotected sex as compared with other psychiatric diagnoses, whereas among women there was no statistical difference. On the other hand, the odds of recent unprotected sex were statistically twice as high among women with no previous HIV testing. Lifetime cigarette smoking, a history of verbal violence, and poor HIV/AIDS knowledge were statistically associated with unprotected sex among women. Among men, the odds of unprotected sex were statistically higher among those who reported one sexual partner in the past six months. On the other hand, men that reported refusal of condom use by partner and receiving or offering money or drugs for sex had lower odds of recent unprotected sex.

For each group of variables, the following characteristics were selected for the overall final logistic model, after the intermediate modeling: age, marital status, schooling, current housing partnership, previous HIV testing; receiving/offering money and/or drugs for sex, sex under the influence of drugs and/or alcohol, cigarette smoking, lifetime verbal, HIV/AIDS knowledge and self-perception of HIV risk for the women stratum; and marital status, family income in the last month, current housing partnership, main psychiatric diagnosis, receiving/offering money and/or drugs for sex, multiple sexual partners in the past six months and cigarette smoking for the men stratum. Multivariate analysis indicated three variables that were independently associated with recent unprotected sex among both men and women $(\mathrm{p}<0.05)$ (Table 3$)$ : to be married or in union, to be living with children and/or a partner, and lifetime cigarette smoking. On the other hand, lower family income and depression and anxiety diagnoses were associated with unprotected sex among men only, while older age, no previous HIV testing, sex under the influence of drugs or alcohol, and a history of verbal violence were statistically associated with unprotected sex among women only.

\section{Discussion}

To our knowledge this is the first study to focus on gender differences of recent sexual risk behavior in a national sample of psychiatric patients in Brazil. The prevalence of recent unprotected sex was high in both genders in our sample, but it was higher among women than men $(89 \%$ and $77 \%$, respectively), and this result was consistent with other studies 4,5 . This is also consistent with our previous data which indicated women to practice lifetime unsafe sex more often than men in Brazil 6. In addition, the prevalence was higher than in the Brazilian population (15 to 64 years old) for both women and men $(78 \%$ and $72 \%$, respectively) 2 . This is consistent with the evidence that people with mental illness are at increased risk of unprotected sex compared with the general population, overall and also among women as compared to men. Condom use is a male-controlled practice posing increased difficulties for women to negotiate its use. In addition, lower intentions to change HIV risk, partner resistant to condom use, coercion and low socioeconomic status and education can be factors contributing to a higher prevalence of condom use among women 5 .

We should note important differences in the correlates of unprotected sex among men and women in our study. While contextual factors (no previous HIV testing, sex under the influence of drugs or alcohol and verbal violence) were independent predictors among women, 
Univariate analysis of recent unprotected sex *, stratified by gender, among sexually active patients with mental illness. PESSOAS Project, Brazil, 2006.

\begin{tabular}{|c|c|c|c|c|c|c|c|c|c|c|}
\hline \multirow[t]{2}{*}{ Characteristics } & \multicolumn{5}{|c|}{ Men $(N=684)$} & \multicolumn{5}{|c|}{ Women $(N=791)$} \\
\hline & Total ** & $\mathrm{n}(\%) \star \star \star$ & OR & $(95 \% \mathrm{Cl})$ & $\chi^{2}$ (p-value) & Total ** & $\mathrm{n}(\%) \star \star \star$ & OR & $(95 \% \mathrm{Cl})$ & $\chi^{2}$ (p-value) \\
\hline \multicolumn{11}{|l|}{ Type of recruitment center } \\
\hline CAPS & 373 & $286(76.7)$ & 0.94 & $(0.65-1.34)$ & $0.12(0.72)$ & 578 & $514(88.3)$ & 1.07 & $(0.65-1.75)$ & $0.07(0.79)$ \\
\hline Hospital & 311 & $242(77.8)$ & 1.00 & & & 213 & $188(88.9)$ & 1.00 & & \\
\hline White & 332 & $255(76.8)$ & 0.96 & $(0.67-1.37)$ & $0.05(0.82)$ & 416 & $365(89.8)$ & 0.81 & $(0.52-1.26)$ & $0.87(0.35)$ \\
\hline Black/Mulatto & 352 & $273(77.6)$ & 1.00 & & & 374 & $336(87.7)$ & 1.00 & & \\
\hline \multicolumn{11}{|l|}{ Age (years) } \\
\hline$>40$ & 311 & $258(83.0)$ & 1.86 & $(1.28-2.70)$ & $10.77(<0.01) \#$ & 394 & $364(92.4)$ & 2.11 & $(1.33-3.37)$ & 10.40 \\
\hline$\leq 40$ & 373 & $270(72.4)$ & 1.00 & & & 397 & $338(85.1)$ & 1.00 & & $(<0.01) \#$ \\
\hline \multicolumn{11}{|l|}{ Schooling (years) } \\
\hline$<5$ & 309 & $245(79.3)$ & 1.26 & $(0.87-1.81)$ & $1.53(0.22)$ & 372 & $344(92.5)$ & 2.10 & $(1.31-3.37)$ & 9.79 \\
\hline$\geq 5$ & 368 & $277(75.3)$ & 1.00 & & & 411 & $351(85.4)$ & 1.00 & & $(<0.01) \#$ \\
\hline \multicolumn{11}{|l|}{$\begin{array}{l}\text { Family income in the last } \\
\text { month \#\# }\end{array}$} \\
\hline$\leq$ US\$ 200 & 129 & $106(82.2)$ & 1.55 & $(0.93-2.59)$ & $2.84(0.09)$ & 222 & $194(87.4)$ & 0.77 & $(0.45-1.30)$ & $0.98(0.32)$ \\
\hline$>$ US\$ 200 & 345 & $258(74.8)$ & 1.00 & & & 361 & $325(90.0)$ & 1.00 & & \\
\hline \multicolumn{11}{|l|}{ Current housing partnership } \\
\hline $\begin{array}{l}\text { Living with children and/or } \\
\text { partner }\end{array}$ & 245 & $223(91.0)$ & 4.45 & $(2.75-7.21)$ & $41.46(<0.01) \#$ & 580 & $533(91.9)$ & 2.87 & $(1.83-4.51)$ & $\begin{array}{c}22.33 \\
(<0.01) \#\end{array}$ \\
\hline \multicolumn{11}{|l|}{ Psychiatric diagnoses (ICD-10) } \\
\hline Depression/Anxiety & 83 & $74(89.2)$ & 3.20 & $(1.42-7.20)$ & $7.93(<0.01) \#$ & 235 & $214(91.1)$ & 1.57 & $(0.83-2.96)$ & $1.93(0.16)$ \\
\hline Substance use disorder & 117 & $93(79.5)$ & 1.51 & $(0.82-2.80)$ & $1.71(0.19)$ & 24 & $21(87.5)$ & 1.08 & $(0.29-3.91)$ & $0.01(0.91)$ \\
\hline Other & 107 & 77 (72.0) & 1.00 & & & 165 & $143(86.7)$ & 1.00 & & \\
\hline \multicolumn{11}{|l|}{ Previous hospitalization } \\
\hline Yes & 423 & $320(75.7)$ & 0.80 & $(0.55-1.16)$ & $1.28(0.24)$ & 365 & $324(88.8)$ & 1.01 & $(0.65-1.57)$ & $0.002(0.97)$ \\
\hline No & 259 & $206(79.5)$ & 1.00 & & & 424 & $376(88.7)$ & 1.00 & & \\
\hline \multicolumn{11}{|l|}{ STD in the past year } \\
\hline Yes & 48 & $39(81.3)$ & 1.32 & $(0.63-2.80)$ & $0.55(0.46)$ & 101 & $92(91.1)$ & 1.32 & $(0.64-2.73)$ & $0.57(0.45)$ \\
\hline No & 615 & $471(76.6)$ & 1.00 & & & 664 & $588(88.6)$ & 1.00 & & \\
\hline \multicolumn{11}{|l|}{ Previous HIV testing } \\
\hline No & 457 & $359(78.6)$ & 1.31 & $(0.90-1.91)$ & $2.02(0.15)$ & 505 & $460(91.1)$ & 2.01 & $(1.29-3.13)$ & 9.68 \\
\hline Yes & 216 & 159 (73.6) & 1.00 & & & 268 & $224(83.6)$ & 1.00 & & $(<0.01) \#$ \\
\hline \multicolumn{11}{|l|}{ Behavioral } \\
\hline \multicolumn{11}{|l|}{$\begin{array}{l}\text { Age of first sexual intercourse } \\
\text { (years) }\end{array}$} \\
\hline$<18$ & 454 & $343(75.6)$ & 0.75 & $(0.50-1.13)$ & $1.92(0.17)$ & 404 & 365 (90.4) & 1.41 & $(0.90-2.21)$ & $2.25(0.13)$ \\
\hline$\geq 18$ & 200 & $161(80.5)$ & 1.00 & & & 367 & 319 (86.9) & 1.00 & & \\
\hline
\end{tabular}

(continues) 
Univariate analysis of recent unprotected sex *, stratified by gender, among sexually active patients with mental illness. PESSOAS Project, Brazil, 2006.

\begin{tabular}{|c|c|c|c|c|c|c|c|c|c|c|}
\hline \multirow[t]{2}{*}{ Characteristics } & \multicolumn{5}{|c|}{ Men $(N=684)$} & \multicolumn{5}{|c|}{ Women $(N=791)$} \\
\hline & Total ** & $\mathrm{n}(\%) * \star \star$ & OR & $(95 \% \mathrm{Cl})$ & $\chi^{2}$ (p-value) & Total ** & $\mathrm{n}(\%) * \star \star$ & OR & $(95 \% \mathrm{Cl})$ & $\chi^{2}$ (p-value) \\
\hline \multicolumn{11}{|l|}{ Behavioral } \\
\hline \multirow{2}{*}{\multicolumn{11}{|c|}{$\begin{array}{l}\text { Refusal of condom use by } \\
\text { partner }\end{array}$}} \\
\hline & & & & & & & & & & \\
\hline Yes & 158 & $111(70.3)$ & 0.63 & $(0.42-0.95)$ & $5.03(0.02) \#$ & 308 & 271 (87.9) & 0.91 & $(0.58-1.42)$ & $0.18(0.67)$ \\
\hline No & 511 & 403 (78.9) & 1.00 & & & 463 & 412 (89.0) & 1.00 & & \\
\hline \multirow{2}{*}{\multicolumn{11}{|c|}{$\begin{array}{l}\text { Received/Offered money or } \\
\text { drugs for sex }\end{array}$}} \\
\hline & & & & & & & & & & \\
\hline Yes & 318 & $232(73.0)$ & 0.63 & $(0.44-0.94)$ & $6.20(0.01) \#$ & 130 & $110(84.6)$ & 0.64 & $(0.37-1.10)$ & $2.69(0.10)$ \\
\hline No & 358 & $290(81.0)$ & 1.00 & & & 653 & $585(89.6)$ & 1.00 & & \\
\hline \multirow{2}{*}{\multicolumn{11}{|c|}{$\begin{array}{l}\text { Sex under the influence of } \\
\text { drugs or alcohol }\end{array}$}} \\
\hline & & & & & & & & & & \\
\hline Yes & 322 & $250(77.6)$ & 1.04 & $(0.72-1.48)$ & $0.04(0.85)$ & 160 & $148(92.5)$ & 1.70 & $(0.90-3.22)$ & $2.76(0.10)$ \\
\hline No & 357 & $275(77.0)$ & 1.00 & & & 626 & $550(87.9)$ & 1.00 & & \\
\hline \multirow{2}{*}{\multicolumn{11}{|c|}{$\begin{array}{l}\text { Number of sexual partners } \\
\text { (past six months) }\end{array}$}} \\
\hline & & & & & & & & & & \\
\hline Only one & 337 & $283(84.0)$ & 2.80 & $(1.89-4.13)$ & $27.73(<0.01) \#$ & 548 & $486(88.7)$ & 1.04 & $(0.57-1.90)$ & $0.02(0.90)$ \\
\hline$>1$ & 250 & $163(65.2)$ & 1.00 & & & 128 & $113(88.3)$ & 1.00 & & \\
\hline \multicolumn{11}{|l|}{ Lifetime alcohol use } \\
\hline Yes & 581 & $450(77.5)$ & 1.12 & $(0.68-1.82)$ & $0.19(0.66)$ & 447 & $398(89.0)$ & 1.07 & $(0.69-1.67)$ & $0.10(0.76)$ \\
\hline No & 102 & $77(75.5)$ & 1.00 & & & 343 & 303 (88.3) & 1.00 & & \\
\hline \multicolumn{11}{|l|}{ Lifetime illicit drug use } \\
\hline Yes & 289 & $221(76.5)$ & 0.92 & $(0.64-1.32)$ & $0.20(0.66)$ & 139 & $123(88.5)$ & 0.97 & $(0.55-1.73)$ & $0.01(0.92)$ \\
\hline No & 394 & 307 (77.9) & 1.00 & & & 651 & $578(88.8)$ & 1.00 & & \\
\hline \multicolumn{11}{|l|}{ Lifetime cigarette smoking } \\
\hline Yes & 566 & $444(78.5)$ & 1.51 & $(0.96-2.36)$ & $3.28(0.07)$ & 506 & $462(91.3)$ & 1.91 & $(1.22-2.98)$ & 8.13 \\
\hline No & 116 & $82(70.7)$ & 1.00 & & & 280 & $237(84.6)$ & 1.00 & & $(<0.01) \#$ \\
\hline \multicolumn{11}{|l|}{ Lifetime verbal violence } \\
\hline Yes & 477 & $368(77.2)$ & 0.99 & $(0.67-1.46)$ & $0.002(0.97)$ & 597 & $536(90.3)$ & 1.78 & $(1.11-2.85)$ & $5.88(0.02) \#$ \\
\hline No & 207 & $160(77.3)$ & 1.00 & & & 193 & 162 (83.9) & 1.00 & & \\
\hline \multicolumn{11}{|l|}{ Lifetime physical violence } \\
\hline Yes & 408 & $318(77.9)$ & 1.13 & $(0.78-1.62)$ & $0.42(0.52)$ & 463 & 416 (89.9) & 1.30 & $(0.84-2.02)$ & $1.35(0.24)$ \\
\hline No & 273 & $207(75.8)$ & 1.00 & & & 328 & $286(87.2)$ & 1.00 & & \\
\hline \multicolumn{11}{|l|}{ Lifetime sexual violence } \\
\hline Yes & 84 & $62(73.8)$ & 0.82 & $(0.48-1.38)$ & $0.57(0.45)$ & 227 & 208 (91.6) & 1.56 & $(0.91-2.65)$ & $2.70(0.10)$ \\
\hline No & 596 & $462(77.5)$ & 1.00 & & & 562 & $492(87.5)$ & 1.00 & & \\
\hline \multicolumn{11}{|l|}{ Knowledge HIV/AIDS } \\
\hline Poor & 241 & 195 (80.9) & 1.44 & $(0.97-2.11)$ & $3.35(0.07)$ & 280 & 257 (91.8) & 1.66 & $(1.01-2.73)$ & $4.00(0.045)$ \\
\hline Good & 431 & $322(74.7)$ & 1.00 & & & 503 & $438(87.1)$ & 1.00 & & \\
\hline \multicolumn{11}{|l|}{ HIV risk self-perception } \\
\hline $\begin{array}{l}\text { High/Some risk/Do not } \\
\text { know }\end{array}$ & 444 & $346(77.9)$ & 1.17 & $(0.80-1.71)$ & $0.66(0.42)$ & 539 & $486(90.2)$ & 1.54 & $(0.96-2.45)$ & $3.31(0.07)$ \\
\hline No risk & 221 & $166(75.1)$ & 1.00 & & & 230 & 197 (85.7) & 1.00 & & \\
\hline
\end{tabular}

95\% Cl: 95\% confidence interval; CAPS: Public Mental Health Outpatient Clinics; ICD-10: 10th revision of the International Classification of Diseases; OR: odds ratio; STD: sexually transmitted diseases.

* Not using condoms in all practices in the last six months;

** Total varies according to missing information;

*** Number and proportion of unprotected sex for each category;

\# Statistically significant $\mathrm{p}<0.05$;

\#\# Minimum wage in $2006=$ US\$ 200. 
Multivariate logistic analysis of recent unprotected sex, stratified by gender, among sexually active patients with mental illness. PESSOAS Project, Brazil, 2006.

\begin{tabular}{|c|c|c|c|c|}
\hline \multirow[t]{2}{*}{ Characteristics } & \multicolumn{2}{|c|}{$\operatorname{Men} *(N=665) * *$} & \multicolumn{2}{|c|}{ Women $* * \star(N=759) * *$} \\
\hline & OR $(95 \% \mathrm{Cl})$ & p-value & OR $(95 \% \mathrm{Cl})$ & $\mathrm{p}$-value \\
\hline Age $>40$ years old & - & - & $1.77(1.08-2.89)$ & $0.02 \#$ \\
\hline To be married or in union & $2.46(1.14-5.32)$ & $0.02 \#$ & $2.22(1.22-4.05)$ & $0.01 \#$ \\
\hline Family income in the last month ( $\leq$ US $\$ 200 \# \#)$ & $1.97(1.15-3.38)$ & $0.01 \#$ & - & - \\
\hline Living with children and/or partner & $2.49(1.14-5.45)$ & $0.02 \#$ & $1.85(1.03-3.31)$ & $0.04 \#$ \\
\hline \multicolumn{5}{|l|}{ Psychiatric diagnoses (ICD-10) } \\
\hline Psychoses/Bipolar disorder/Depression with psychotic symptoms & $1.33(0.79-2.23)$ & 0.29 & - & - \\
\hline Depression/Anxiety & $2.63(1.10-6.27)$ & $0.03 \#$ & - & - \\
\hline Substance use disorder & $1.85(0.95-3.60)$ & 0.07 & - & - \\
\hline No previous HIV testing & - & - & $2.06(1.27-3.34)$ & $<0.01 \#$ \\
\hline Sex under the influence of drugs or alcohol & - & - & $2.52(1.14-4.46)$ & $0.02 \#$ \\
\hline Lifetime verbal violence & - & - & $1.71(1.02-2.85)$ & $0.04 \#$ \\
\hline Lifetime cigarette smoking & $1.86(1.13-3.07)$ & $0.01 *$ & $1.87(1.16-3.03)$ & $0.01 \#$ \\
\hline
\end{tabular}

95\% Cl: $95 \%$ confidence interval; ICD-10: 10 th revision of the International Classification of Diseases; OR: odds ratio.

* Hosmer-Lemeshow test: $\chi^{2}=7.79 ; \mathrm{df}=8 ; \mathrm{p}=0.45$;

** Excluded missing information;

*** Hosmer-Lemeshow test: $\chi^{2}=2.24 ; \mathrm{df}=8 ; \mathrm{p}=0.97$;

\# Statistically significant $p<0.05$;

\#\# Brazilian minimum wage in $2006=$ US\$ 200 .

psychiatric diagnosis (depression and anxiety) was only associated with unprotected sex among men. In addition, sociodemographic differences were observed (lower family income among men and older age among women). However, other factors were equally associated with unprotected sex in both men and women (marital status, living with partners or children and cigarette smoking).

More severe psychiatric diagnoses, such as psychoses, can negatively interfere in the interest and ability to initiate and maintain a sexual relationship, while other psychiatric diagnoses may favor impulsivity, decrease risk awareness and social skills, thereby reducing the ability to make decisions, negotiate condoms and adopt and maintain preventive behaviors 6,9 . We should point out that the association between depression and anxiety and unprotected sex among men may only indicate a need to focus on equal access to HIV prevention in these services regardless of severity of diagnoses or substance use disorders. However, further studies are needed to fully understand this difference.

Consistent with previous research, participants who were married or in union, a marker for stable relationships, were more likely to practice recent unprotected sex among both men and women 1,5. Stable relationships are usually based on trust and loyalty, and the request for condom use by one of the partners may weaken this relationship and may generate distrust, as it is generally acceptable for contraception purposes, rather than for protection against STD among stable couples $3,18,19$. In addition, living with a partner and/or children was a significant contextual factor associated with an increased risk of unprotected sex among both, men and women. It is likely that this variable acts as a potential marker for lack of privacy, which may contribute to unprotected sex among stable couples 6 . Lower family income was associated with unprotected sex among men only. Other studies have also found an association between low socio-economic status and inconsistent condom use 20,21 . In a qualitative study with men without psychiatric disorders, one of the reasons for not using condoms was attributed to the high cost of this input 22. Moreover, these findings suggest that men with low income may have the least information about forms of HIV transmission and low decision-making power within their relationships to practice safe sex 20,21 . On the other hand, older age ( $>40$ years old) was associated with higher odds of unprotected sex among women only. This result is consistent with others studies among populations with psychiatric disorders and with women without mental illness 6,21. 
Lower HIV knowledge, poor levels of motivation and skills for condom use, and gender-based differences such as lower decision making power among older women could partially explain this result 23 . Not having been tested for HIV was a factor associated with recent unprotected sex among women only. Although our results differ from other studies 24,25 , this result is important and can indicate low information and motivation of women with mental disorders to protect themselves and seek health care, including HIV testing. In addition, it also indicates that direct approach and attention for HIV prevention and care in these mental health services in Brazil may be lacking.

Finally, while cigarette smoking was associated with unprotected sex among both genders, sex under the influence of alcohol or drugs, and having suffered any verbal violence were independent correlates of unprotected sex among women only, and this result was consistent with other studies 26,27,28,29,30,31. Sex under the influence of alcohol or drugs can alter cognitive abilities and decision-making power, thus potentially leading to high risk behaviors 6 . Similarly, violence among women with mental illness may diminish their ability to enact safer sex 30 . These are evidence that emphasize the potential higher vulnerability of women to HIV in this population, and thus the need for specific and integrated prevention actions, while smoking may be seen as an overall marker of risky sexual behavior 25 .

\section{Resumen}

Este estudio estima la prevalencia y los factores asociados con el sexo no protegido reciente entre los pacientes psiquiátricos sexualmente activos en Brasil, estratificado por sexo. La prevalencia de relaciones sexuales sin protección entre hombres y mujeres fue de $89 \%$ y $77 \%$, respectivamente. Los factores asociados significativamente con el sexo sin protección fueron: estar casado/ en unión, vivir con los niños/pareja, y el tabaquismo en ambos sexos; bajos ingresos y diagnóstico de depresión y ansiedad entre los hombres solamente; edad mayor de
Limitations of our results include a potential underestimation of unprotected sex due to the exclusion of patients with more severe mental illness who were unable to participate in the study, and also services that exclusively treated substance use disorders as primary diagnoses. In addition, our study is limited to those who had access to mental health services in Brazil, which impairs the generalization to all psychiatric patients and the cross-sectional design of the study limits our ability to assess direct cause-effect relationships. However, there is no reason to believe our results are in any way biased.

In conclusion, our study emphasizes the high rate of unprotected sex among these sexually active psychiatric patients, especially among women. Prevention programs that include strategies for changing risk behaviors should be developed for patients with psychiatric disorders, specifically for women. Because these patients are under care within the public system, mental health professionals must direct efforts to avoid missing opportunities for HIV prevention. Screening for risky behavior, encouraging condom use in this population, counseling, and HIV testing at the sites should be routine procedures. Also, efforts should be made to ensure a complete and integral assistance to this population, with trained professionals and an appropriate structure for conducting health prevention and care actions.
40 años, ninguna prueba anterior para VIH, sexo bajo la influencia de alcohol/drogas y la violencia verbal sólo entre las mujeres. Las intervenciones para reducir los comportamientos de riesgo entre los pacientes psiquiátricos en Brasil son urgentes y deben considerar las diferencias de género.

VIH; Conducta Sexual; Trastornos Mentales 


\section{Contributors}

E. R. M. Peixoto contributed to the conception of the study, the analysis and interpretation of the data, the statistical analysis and writing of the manuscript. F. C. R. Barros contributed to the analysis and interpretation of the data and relevant critical review of the intellectual content. M. D. C. Guimarães was responsible for the conception, design and conduct of the study, the statistical analysis, analysis and interpretation of the data, and writing and approval of the final version for submission.

\section{Acknowledgments}

This work was carried out by the Minas Gerais Federal University with technical and financial support of the Brazilian Ministry of Health/Secretariat of Health Surveillance/Department of STD, AIDS and Viral Hepatitis through the Project of International Technical Cooperation 914/BRA/1101 between the Brazilian Government and UNESCO. We thank Carla Jorge Machado for her valuable comments during the preparation of the manuscript.

\section{References}

1. Meade CS, Sikkema KJ. HIV risk behavior among adults with severe mental illness: a systematic review. Clin Psychol Rev 2005; 25:433-57.

2. Departamento de DST, AIDS e Hepatites Virais, Secretaria de Vigilância em Saúde, Ministério da Saúde. Pesquisa de conhecimentos, atitudes e práticas na população brasileira, 2008. Brasília: Ministério da Saúde; 2011. (Série G. Estatística e Informação em Saúde).

3. Wainberg M, McKinnon K, Elkington KS, Mattos PE, Gruber Mann C, De Souza Pinto D, et al. HIV risk behaviors among outpatients with severe mental illness in Rio de Janeiro, Brazil. World Psychiatry 2008; 7:166-72.

4. Devieux JG, Malow R, Lerner BG, Dyer JG, Baptista, Lucenko B, et al. Triple jeopardy for HIV: substance using severely mentally ill adults. J Prev Interv Community 2007; 33:5-18.
5. Meade CS, Sikkema KJ. Psychiatric and psychosocial correlates of sexual risk behavior among adults with severe mental illness. Community Ment Health J 2007; 43:153-69.

6. Guimarães MD, McKinnon K, Campos LN, Melo AP, Wainberg M. HIV risk behavior of psychiatric patients with mental illness: a sample of Brazilian patients. Rev Bras Psiquiatr 2010; 32:351-60.

7. Eaton DK, Kann L, Kinchen S, Shanklin S, Flint KH, Hawkins J, et al. Youth risk behavior surveillance United States, 2011. MMWR Surveill Summ 2012; 61:1-162.

8. Harrison A, O'Sullivan LF, Hoffman S, Dolezal C, Morrell R. Gender role and relationship norms among young adults in South Africa: measuring the context of masculinity and HIV risk. J Urban Health 2006; 83:709-22. 
9. Carey MP, Carey KB, Maisto SA, Schroder KEE, Vanable PA, Gordon CM. HIV risk behavior among psychiatric outpatients: association with psychiatric disorder, substance use disorder, and gender. J Nerv Ment Dis 2004; 192:289-96.

10. Johnson JL, Ratner PA, Malchy LA, Okoli CT, Procyshyn RM, Bottorff JL, et al. Gender-specific profiles of tobacco use among non-institutionalized people with serious mental illness. BMC Psychiatry 2010; 10:101.

11. Cotton SM, Lambert M, Schimmelmann BG, Foley DL, Morley KI, McGorry PD, et al. Gender differences in premorbid, entry, treatment, and outcome characteristics in a treated epidemiological sample of 661 patients with first episode psychosis. Schizophr Res 2009; 114:17-24.

12. Abel KM, Drake R, Goldstein JM. Sex differences in schizophrenia. Int Rev Psychiatry 2010; 22:417-28.

13. Parker G, Brotchie H. Gender differences in depression. Int Rev Psychiatry 2010; 22:429-36.

14. Gaviria SL, Rondon MB. Some considerations on women's mental health in Latin America and the Caribbean. Int Rev Psychiatry 2010; 22:363-9.

15. Diflorio A, Jones I. Is sex important? Gender differences in bipolar disorder. Int Rev Psychiatry 2010; 22:437-52.

16. Guimarães MD, Campos LN, Melo AP, Carmo RA, Machado CJ, Acurcio FA, et al. Prevalence of HIV, syphilis, hepatitis B and C among adults with mental illness: a multicenter study in Brazil. Rev Bras Psiquiatr 2009; 31:43-7.

17. Centro Colaborador da OMS para a Classificação de Doenças. Classificação estatística internacional de doenças e problemas relacionados à saúde - CID-10. 2a Ed. São Paulo: Organização Mundial da Saúde; 2004.

18. Chamratrithirong A, Kaiser P. The dynamics of condom use with regular and casual partners: analysis of the 2006 national sexual behavior survey of Thailand. PLoS One 2012; 7:e420009.

19. Maia C, Guilherm D, Freitas D. Vulnerability to HIV/AIDS in married heterosexual people or people in a common-law marriage. Rev Saúde Pública 2008; 42:242-8.

20. Davidoff-Gore A, Luke N, Wawire S. Dimensions of poverty and inconsistent condom use among youth in urban Kenya. AIDS Care 2011; 23:1282-90.
21. Szwarcwald CL, Barbosa-Júnior A, Pascom AR, de Souza-Júnior PR. Knowledge, practices and behaviours related to HIV transmission among the Brazilian population in the 15-54 years age group, 2004. AIDS 2005; 19 Suppl 4:S51-8.

22. Guerriero I, Ayres JR, Hearst N. Masculinity and vulnerability to HIV among heterosexual men in São Paulo, Brazil. Rev Saúde Pública 2002; 36(4 Suppl):50-60.

23. Olivi M, Santana RG, Mathias TAF. Behavior, knowledge and perception of risks about sexually transmitted diseases in a group of people over 50 years old. Rev Latinoam Enferm 2008; 16:679-85.

24. Senn TE, Carey MP. HIV testing among individuals with a severe mental illness: review, suggestions for research, and clinical implications. Psychol Med 2009; 39:355-63.

25. Weinhardt LS, Carey MP, Carey KB. HIV risk behavior and the public health context of HIV/AIDS among women living with a severe and persistent mental illness. J Nerv Ment Dis 1998; 186:276-82.

26. Villanti A, German D, Sifakis F, Flynn C, Holtgrave D. Smoking, HIV status, and HIV risk behaviors in a respondent-driven sample of injection drug users in Baltimore, Maryland: The BeSure Study. AIDS Educ Prev 2012; 24:132-47.

27. Wolf R, Freedman D. Cigarette smoking, sexually transmitted diseases, and HIV/AIDS. Int J Dermatol 2000; 39:1-9.

28. Randolph ME, Pinkerton SD, Somlai AM, Kelly JA, McAuliffe TL, Gibson RH, et al. Severely mentally ill women's HIV risk: the influence of social support, substance use, and contextual risk factors. Community Ment Health J 2007; 43:33-47.

29. Meyer JP, Spreinger SA, Altice FL. Substance abuse, violence, and HIV in women: a literature review of the syndemic. J Womens Health (Larchmt) 2011; 20:991-1006.

30. Fair CD, Vanyur J. Sexual coercion, verbal aggression, and condom use consistency among college students. J Am Coll Health 2011; 59:273-80.

31. Mittal M, Senn TE, Carey MP. Intimate partner violence and condom use among women: does the information-motivation-behavioral skills model explain sexual risk behavior? AIDS Behav 2012; 16:1011-9.

Submitted on $14 / \mathrm{Feb} / 2013$

Final version resubmitted on 30/Aug/2013

Approved on 25/Nov/2013 